\title{
Blood coagulation components in GtoPdb v.2021.2
}

\author{
Szu S. Wong ${ }^{1}$
}

1. Keele University, UK

\begin{abstract}
Coagulation as a process is interpreted as a mechanism for reducing excessive blood loss through the generation of a gel-like clot local to the site of injury. The process involves the activation, adhesion (see Integrins), degranulation and aggregation of platelets, as well as proteins circulating in the plasma. The coagulation cascade involves multiple proteins being converted to more active forms from less active precursors (for example, prothrombin [Factor II] is converted to thrombin [Factor IIa]), typically through proteolysis (see Proteases). Listed here are the components of the coagulation cascade targeted by agents in current clinical usage or at an advanced level of development.
\end{abstract}

\section{Contents}

This is a citation summary for Blood coagulation components in the Guide to Pharmacology database (GtoPdb). It exists purely as an adjunct to the database to facilitate the recognition of citations to and from the database by citation analyzers. Readers will almost certainly want to visit the relevant sections of the database which are given here under database links.

GtoPdb is an expert-driven guide to pharmacological targets and the substances that act on them. GtoPdb is a reference work which is most usefully represented as an on-line database. As in any publication this work should be appropriately cited, and the papers it cites should also be recognized. This document provides a citation for the relevant parts of the database, and also provides a reference list for the research cited by those parts. For further details see [2].

Please note that the database version for the citations given in GtoPdb are to the most recent preceding version in which the family or its subfamilies and targets were substantially changed. The links below are to the current version. If you need to consult the cited version, rather than the most recent version, please contact the GtoPdb curators.

\section{Database links}

Blood coagulation components

https://www.guidetopharmacology.org/GRAC/FamilyDisplayForward?familyId=853

Enzymes

coagulation factor II, thrombin

https://www.guidetopharmacology.org/GRAC/ObjectDisplayForward?objectId=2362 coagulation factor $\mathrm{V}$

https://www.guidetopharmacology.org/GRAC/ObjectDisplayForward?objectId=2606 coagulation factor VIII

https://www.guidetopharmacology.org/GRAC/ObjectDisplayForward?objectId=2607 coagulation factor $\mathrm{X}$

https://www.guidetopharmacology.org/GRAC/ObjectDisplayForward?objectId=2359 coagulation factor XI

https://www.guidetopharmacology.org/GRAC/ObjectDisplayForward?objectId=2360 antithrombin, antithrombin III(serpin family C member 1)

https://www.guidetopharmacology.org/GRAC/ObjectDisplayForward?objectId=2632

\section{References}

1. AstraZeneca. AZ12971554.

2. Buneman P, Christie G, Davies JA, Dimitrellou R, Harding SD, Pawson AJ, Sharman JL and Wu Y. 
(2020) Why data citation isn't working, and what to do about it Database 2020 [PMID:32367113]

3. Cziraky MJ and Spinler SA. (1993) Low-molecular-weight heparins for the treatment of deepvein thrombosis. Clin Pharm 12: 892-9 [PMID:8137606]

4. Deinum J, Mattsson C, Inghardt T and Elg M. (2009) Biochemical and pharmacological effects of the direct thrombin inhibitor AR-H067637. Thromb Haemost 101: 1051-9 [PMID:19492147]

5. Eriksson BI, Söderberg K, Widlund L, Wandeli B, Tengborn L and Risberg B. (1995) A comparative study of three low-molecular weight heparins (LMWH) and unfractionated heparin (UH) in healthy volunteers. Thromb Haemost 73: 398-401 [PMID:7667822]

6. Eriksson BI, Wille-Jørgensen P, Kälebo P, Mouret P, Rosencher N, Bösch P, Baur M, Ekman S, Bach D and Lindbratt $S$ et al.. (1997) A comparison of recombinant hirudin with a lowmolecular-weight heparin to prevent thromboembolic complications after total hip replacement. N Engl J Med 337: 1329-35 [PMID:9358126]

7. Friedel HA and Balfour JA. (1994) Tinzaparin. A review of its pharmacology and clinical potential in the prevention and treatment of thromboembolic disorders. Drugs 48: 638-60 [PMID:7528134]

8. Furugohri T, Isobe K, Honda Y, Kamisato-Matsumoto C, Sugiyama N, Nagahara T, Morishima Y and Shibano T. (2008) DU-176b, a potent and orally active factor Xa inhibitor: in vitro and in vivo pharmacological profiles. J Thromb Haemost 6: 1542-9 [PMID:18624979]

9. Gailani D and Gruber A. (2016) Factor XI as a Therapeutic Target. Arterioscler Thromb Vasc Biol 36: 1316-22 [PMID:27174099]

10. Galemmo RA Jr., Fevig JM, Carini DJ, Cacciola J, Wells BL, Hillyer GL, Buriak J Jr., Rossi KA, Stouten PFW and Alexander RS et al.. (1996) (N-acyl-N-alkyl)glycyl borolysine analogs: A new class of potent thrombin inhibitors. Bioorg Med Chem Lett 6: 2913-2918

11. Gotti R, Parma B, Spelta F and Liverani L. (2013) Affinity capillary electrophoresis in binding study of antithrombin to heparin from different sources. Talanta 105: 366-71 [PMID:23598032]

12. Guertin KR, Gardner CJ, Klein SI, Zulli AL, Czekaj M, Gong Y, Spada AP, Cheney DL, Maignan S and Guilloteau JP et al.. (2002) Optimization of the beta-aminoester class of factor Xa inhibitors. Part 2: Identification of FXV673 as a potent and selective inhibitor with excellent In vivo anticoagulant activity. Bioorg Med Chem Lett 12: 1671-4 [PMID:12039587]

13. Gustafsson D, Antonsson T, Bylund R, Eriksson U, Gyzander E, Nilsson I, Elg M, Mattsson C, Deinum J and Pehrsson S et al.. (1998) Effects of melagatran, a new low-molecular-weight thrombin inhibitor, on thrombin and fibrinolytic enzymes. Thromb Haemost 79: 110-8 [PMID:9459334]

14. Hara T, Yokoyama A, Ishihara H, Yokoyama Y, Nagahara T and Iwamoto M. (1994) DX-9065a, a new synthetic, potent anticoagulant and selective inhibitor for factor Xa. Thromb Haemost 71 : 314-9 [PMID:8029795]

15. Hauel NH, Nar H, Priepke H, Ries U, Stassen JM and Wienen W. (2002) Structure-based design of novel potent nonpeptide thrombin inhibitors. J Med Chem 45: 1757-66 [PMID:11960487]

16. Hayashi M, Hamada A, Okaya Y, Wakitani K and Aisaka K. (2001) Inhibitory effect of JTV-803, a new cyclic guanidine derivative, on factor Xa in vitro and in vivo. Eur J Pharmacol 428: 163-8 [PMID:11675032]

17. Holmer E, Söderberg K, Bergqvist D and Lindahl U. (1986) Heparin and its low molecular weight derivatives: anticoagulant and antithrombotic properties. Haemostasis 16 Suppl 2: 1-7 [PMID:3744129]

18. Ieko M, Tarumi T, Takeda M, Naito S, Nakabayashi T and Koike T. (2004) Synthetic selective inhibitors of coagulation factor Xa strongly inhibit thrombin generation without affecting initial thrombin forming time necessary for platelet activation in hemostasis. $J$ Thromb Haemost 2: 612-8 [PMID:15102016]

19. Imiya $\mathrm{M}$ and Matsuo T. (1997) Inhibition of collagen-induced platelet aggregation by argatroban in patients with acute cerebral infarction. Thromb Res 88: 245-50 [PMID:9361377]

20. Johnson PH, Sze P, Winant RC, Hudson D, Underhill P, Lazar JB, Olsen C and Almquist R. (1991) Structure-function and refolding studies of the thrombin-specific inhibitor hirudin. Haemostasis 21 Suppl 1: 41-8 [PMID:1894196]

21. Kanji S, Devlin JW, Piekos KA and Racine E. (2001) Recombinant human activated protein C, drotrecogin alfa (activated): a novel therapy for severe sepsis. Pharmacotherapy 21: 1389-402 [PMID:11714212]

22. Kapur S, Kupfer Y and Tessler S. (2001) Recombinant human activated protein C for severe sepsis. N Engl J Med 345: 219-20; author reply 220-1 [PMID:11463021]

23. Kitazawa T, Esaki K, Tachibana T, Ishii S, Soeda T, Muto A, Kawabe Y, Igawa T, Tsunoda H and Nogami K et al.. (2017) Factor VIIIa-mimetic cofactor activity of a bispecific antibody to factors IX/IXa and X/Xa, emicizumab, depends on its ability to bridge the antigens. Thromb Haemost 117: 1348-1357 [PMID:28451690]

24. Macedo-Ribeiro S, Bode W, Huber R, Quinn-Allen MA, Kim SW, Ortel TL, Bourenkov GP, Bartunik HD, Stubbs MT and Kane WH et al.. (1999) Crystal structures of the membrane- 
binding C2 domain of human coagulation factor V. Nature 402: 434-9 [PMID:10586886]

25. Maryanoff BE and Costanzo MJ. (2008) Inhibitors of proteases and amide hydrolases that employ an alpha-ketoheterocycle as a key enabling functionality. Bioorg Med Chem 16: 1562-95 [PMID:18053726]

26. Meijers JC, Tekelenburg WL, Bouma BN, Bertina RM and Rosendaal FR. (2000) High levels of coagulation factor XI as a risk factor for venous thrombosis. $N$ Engl J Med 342: 696-701 [PMID:10706899]

27. Nakase J, Toribatake Y, Mouri Y, Seki H, Kitaoka K and Tomita K. (2009) Heparin versus danaproid for prevention of venous thromboembolism after hip surgery. J Orthop Surg (Hong Kong) 17: 6-9 [PMID:19398784]

28. Ngo JC, Huang M, Roth DA, Furie BC and Furie B. (2008) Crystal structure of human factor VIII: implications for the formation of the factor IXa-factor VIIIa complex. Structure 16: 597-606 [PMID:18400180]

29. Oelschläger C, Römisch J, Staubitz A, Stauss H, Leithäuser B, Tillmanns H and Hölschermann H. (2002) Antithrombin III inhibits nuclear factor kappaB activation in human monocytes and vascular endothelial cells. Blood 99: 4015-20 [PMID:12010802]

30. Paolucci F, Claviés MC, Donat F and Necciari J. (2002) Fondaparinux sodium mechanism of action: identification of specific binding to purified and human plasma-derived proteins. Clin Pharmacokinet 41 Suppl 2: 11-8 [PMID:12383040]

31. Perzborn E, Strassburger J, Wilmen A, Pohlmann J, Roehrig S, Schlemmer KH and Straub A. (2005) In vitro and in vivo studies of the novel antithrombotic agent BAY 59-7939--an oral, direct Factor Xa inhibitor. J Thromb Haemost 3: 514-21 [PMID:15748242]

32. Pinto DJ, Smallheer JM, Cheney DL, Knabb RM and Wexler RR. (2010) Factor Xa inhibitors: next-generation antithrombotic agents. J Med Chem 53: 6243-74 [PMID:20503967]

33. Pinto DJP, Orwat MJ, Smith 2nd LM, Quan ML, Lam PYS, Rossi KA, Apedo A, Bozarth JM, Wu Y and Zheng JJ et al.. (2017) Discovery of a Parenteral Small Molecule Coagulation Factor XIa Inhibitor Clinical Candidate (BMS-962212). J Med Chem 60: 9703-9723 [PMID:29077405]

34. Qiu X, Zhou J, Wang W, Zhao Z, Tang L and Sun S. (2019) Effect of a new inhibitor of factor Xa zifaxaban, on thrombosis in the inferior vena cava in rabbits. J Thromb Thrombolysis 47: 80-86 [PMID:30298304]

35. Salomon O, Steinberg DM, Koren-Morag N, Tanne D and Seligsohn U. (2008) Reduced incidence of ischemic stroke in patients with severe factor XI deficiency. Blood 111: 4113-7 [PMID:18268095]

36. Schaefer M, Buchmueller A, Dittmer F, Straßburger J and Wilmen A. (2019) Allosteric Inhibition as a New Mode of Action for BAY 1213790, a Neutralizing Antibody Targeting the Activated Form of Coagulation Factor XI. J Mol Biol 431: 4817-4833 [PMID:31655039]

37. Seidel H and Kolde HJ. (2018) Monitoring of Argatroban and Lepirudin: What is the Input of Laboratory Values in "Real Life"? Clin Appl Thromb Hemost 24: 287-294 [PMID:28320219]

38. Smits NC, Kobayashi T, Srivastava PK, Skopelja S, Ivy JA, Elwood DJ, Stan RV, Tsongalis GJ, Sellke FW and Gross PL et al.. (2017) HS3ST1 genotype regulates antithrombin's inflammomodulatory tone and associates with atherosclerosis. Matrix Biol 63: 69-90 [PMID:28126521]

39. Stone GW, McLaurin BT, Cox DA, Bertrand ME, Lincoff AM, Moses JW, White HD, Pocock SJ, Ware JH and Feit F et al.. (2006) Bivalirudin for patients with acute coronary syndromes. N Engl J Med 355: 2203-16 [PMID:17124018]

40. van Boven HH and Lane DA. (1997) Antithrombin and its inherited deficiency states. Semin Hematol 34: 188-204 [PMID:9241705]

41. Van Huis CA, Casimiro-Garcia A, Bigge CF, Cody WL, Dudley DA, Filipski KJ, Heemstra RJ, Kohrt JT, Leadley Jr RJ and Narasimhan LS et al.. (2009) Exploration of 4,4-disubstituted pyrrolidine-1,2-dicarboxamides as potent, orally active Factor Xa inhibitors with extended duration of action. Bioorg Med Chem 17: 2501-11 [PMID:19231206]

42. Walenga JM, Jeske WP, Samama MM, Frapaise FX, Bick RL and Fareed J. (2002) Fondaparinux: a synthetic heparin pentasaccharide as a new antithrombotic agent. Expert Opin Investig Drugs 11: 397-407 [PMID:11866668]

43. Warkentin TE, Greinacher A, Craven S, Dewar L, Sheppard JA and Ofosu FA. (2005) Differences in the clinically effective molar concentrations of four direct thrombin inhibitors explain their variable prothrombin time prolongation. Thromb Haemost 94: 958-64 [PMID:16363236]

44. Wienen W, Stassen J-M, Priepke H, Ries UJ and Hauel N. (2007) In-vitro profile and ex-vivo anticoagulant activity of the direct thrombin inhibitor dabigatran and its orally active prodrug, dabigatran etexilate Thrombosis and Haemostasis 98: 155-162

45. Witting JI, Bourdon P, Brezniak DV, Maraganore JM and Fenton 2nd JW. (1992) Thrombinspecific inhibition by and slow cleavage of hirulog-1. Biochem J 283 ( Pt 3): 737-43 [PMID:1290488]

46. Wong PC, Crain EJ, Xin B, Wexler RR, Lam PY, Pinto DJ, Luettgen JM and Knabb RM. (2008) Apixaban, an oral, direct and highly selective factor Xa inhibitor: in vitro, antithrombotic and 
antihemostatic studies. J Thromb Haemost 6: 820-9 [PMID:18315548]

47. Yamauchi T, Umeda F, Inoguchi $T$ and Nawata H. (1989) Antithrombin III stimulates prostacyclin production by cultured aortic endothelial cells. Biochem Biophys Res Commun 163: 1404-11 [PMID:2675842]

48. Zhang P, Huang W, Wang L, Bao L, Jia ZJ, Bauer SM, Goldman EA, Probst GD, Song Y and Su T et al.. (2009) Discovery of betrixaban (PRT054021), N-(5-chloropyridin-2-yl)-2-(4-(N,Ndimethylcarbamimidoyl)benzamido)-5-methoxybenzamide, a highly potent, selective, and orally efficacious factor Xa inhibitor. Bioorg Med Chem Lett 19: 2179-85 [PMID:19297154] 